\title{
PERAN NON PERFORMING FINANCING (NPF) DALAM HUBUNGAN ANTARA DEWAN KOMISARIS INDEPENDEN DAN PROFITABILITAS BANK SYARIAH
}

\author{
Taufikur Rahman, SE.,M.Si \\ takur067782@yahoo.co.id \\ Dian Safitrie, SE \\ ieant_safietrie@yahoo.com
}

\begin{abstract}
This study empirically examined the role of Non Performing Financing (NPF) as the intervening variable on the relationship between independent board and profitability. The population used in this study is all Islamic banking of Indonesia that consist of 13 Islamic banking. The writer took 11 Islamic banking as the sample of this research. The sampling technique used in this research is purposive sampling technique.Types of data used are secondary data. The data of this study collected from Islamic Banking companies that issue an annual report and a report on the implementation of good corporate governance periode of 2011-2015. This study has utilized path analysis to analyze the mediating effect of NPF on the relationship between board size independence and profitability. The result of this study suggest that empirically NPF does not mediate the relationship between independent board and profitability, so empirically NPF can not play the role as the intervening variable. The result of this study also suggest that independent board has positif effect on profitability (ROE), independent board has negative effect on NPF and NPF has not effect on profitability (ROA).
\end{abstract}

Keywords: independent board, Non Performing Financing (NPF), profitability (ROE).

\section{A. PENDAHULUAN}

Lembaga perbankan merupakan salah satu komponen penting dalam melancarkan roda kehidupan perekonomian suatunegara, sehingga kesejahteraan dan taraf hidup rakyatnya meningkat, tidak terkecuali di Indonesia.Peran penting perbankan merupakan implementasi dari apa yang tertuang dalam UndangUndang RI Nomor 10 Tahun 1998 yang menyatakan bahwa bank adalah badan 
usaha yang menghimpun dana dari masyarakat dalam bentuk simpanan dan menyalurkannya kepada masyarakat dalam bentuk kredit dan/atau bentuk-bentuk lainnya dalam rangka meningkatkan taraf hidup rakyat banyak.

Bank konvensional maupun bank yang berprinsip syariah merupakan perusahaan profit oriented yang memiliki tujuan utama yang sama yakni memperoleh laba atau keuntungan.Namun, pada perbankan syariah selain memiliki tujuan yang bersifat komersial juga bersifat sosial yang menjadikan bank syariah berbeda dengan bank konvensional.Orientasi pada laba tersebut menyebabkan terjadinya persaingan antar lembaga perbankan semakin kompetitifsekarang ini.Setiap bank berusaha merebut pasar yang ada dengan berbagai strategi yang dimiliki. Persaingan dapat terjadi antar bank konvensional, kemudian antara bank konvensional dengan bank syariah ataupun antar perbankan syariah yang notabene memiliki prinsip yang sama yakni syariah. Bahkan, terutama perbankan syariah juga harus menghadapi pesaing lain yakni lembaga keuangan lain non bank misalnya koperasi syariah (BMT) dan lembaga keuangan lainnya.

Modal utama perbankanuntuk dapat bertahan dan memenangkan persaingan adalah kepercayaan (trust).Artinya, semakin tinggi kepercayaan masyarakat terhadap suatu bank, maka masyarakat akan semakin berminatuntuk bertransaksi dan menjadi nasabah bank tersebut.Untuk mendapatkan kepercayaan, salah satu yang harus dilakukan bank adalah menerapkantata kelola perusahaan yang baik atau dikenal dengan Good Corporate Governance (GCG).Seperti halnya bank syariah, bank syariah tidak hanya berlabel syariah saja, tetapi juga harus memiliki sikap profesionalisme.KonsepGood Corporate Governance merupakan salah satu konsep yang dapat dijadikan instrumen untuk menilai kesuksesan terhadap suatu organisasi.

Menurut Indroes (2011: 249) tata kelola perusahaan yang baik (good corporate governance/GCG) di industri perbankan dideskripsikan sebagai suatu hubungan antara dewan komisaris, dewan direktur eksekutif, pemangku kepentingan (stakeholder) dan pemegang saham.Dalam Surat edaran Bank Indonesia No. 12/13/DPbS tahun 2010 menyatakan bahwa dalam pelaksanaan 
GCG, Bank perlu melakukan check and balance, menghindari benturan kepentingan (conflict of interest) dalam pelaksanaan tugas serta meningkatkan perlindungan bagi kepentingan stakeholders khususnya nasabah pemilik dana dan pemegang saham minoritas, sehingga secara internal diperlukan keberadaan komisaris independen dan pihak independen. Penelitian yang dilakukan Wardani (2007) menunjukkan bahwa komisaris independen dapat bertindak sebagai penengah dalam perselisihan yang terjadi diantara para manajer internal dan mengawasi kebijakan manajemen serta memberikan nasihat kepada manajemen. Komisaris independen merupakan posisi terbaik untuk melaksanakan fungsi monitoring agar tercipta perusahaan yang good corporate governance.

Penerapan good corporate governancedapat memberikan manfaat bagi perbankan dalam rangka memenangkan persaingan.Salah satu manfaat penerapan good corporate governance bagi perbankan yaitubank memiliki manajemen risiko yang baik.Banyaknya kebutuhan dan keinginan masyarakat dalam hal pembiayaan, maka suatu perbankan syariah harus dapat mengelola risiko yang terjadi terutama adalah risiko pembiayaan.Dengan penerapan GCG maka diharapkan dapat meminimalisir risiko pembiayaan padabank syariah, sehingga tingkat profitabilitas bank syariahjuga akansemakin meningkat. Hal tersebut karenagood corporate governance pada dasarnya memiliki tujuan untuk meningkatkan kinerja bank syariah, khususnya untuk meningkatkan profitabilitas atau keuntungan bagi bank syariah tersebut.

Penelitian ini bertujuan untuk melakukan analisis bagaimana peran Non Performing Finance (NPF) dalam hubungan antara good corporate governance(yang diproksikan dengan dewan komisaris independen)dengantingkat profitabilitas (yang diproksikanReturn on Equity).

\section{B. PEMBAHASAN}

\section{Good Corporate Governance (GCG)}

Good Corporate Governance (GCG) menurut World Bank, merupakan kumpulan hukum, peraturan, dan kaidah-kaidah yang wajib dipenuhi yang dapat mendorong kinerja sumber-sumber perusahaan bekerja secara efisien, menghasilkan nilai ekonomi jangka panjang yang berkesinambungan, bagi para 
pemegang saham maupun masyarakat sekitar secara keseluruhan (Muhammad, 2013). Menurut Indroes (2011) tata kelola perusahaan yang baik (good corporate governance/GCG) di industri perbankan dideskripsikan sebagai suatu hubungan antara dewan komisaris, dewan direktur eksekutif, pemangku kepentingan (stakeholders) dan pemegang saham.

Praktik tata kelola yang efektif merupakan salah satu prasyarat utama untuk meraih dan menjaga kepercayaan publik serta dalam arti lebih luas, kepercayaan terhadap sistem perbankan.Tata kelola yang buruk dapat meningkatkan kemungkinan kegagalan sebuah bank.Kegagalan bank dapat menimbulkan biaya publik yang signifikan, mempengaruhi skema jaminan simpanan, dan meningkatkan pengaruh negatif terhadap risiko.Tata kelola perusahaan yang sehat dapat menciptakan lingkungan yang mendukung antara lain dalam bentuk efisiensi perbankan, meringankan risiko keuangan, dan meningkatkan stabilitas sistemik. Pemberi pinjaman dan penyedia dana lain lebih mungkin untuk memberikan pembiayaan ketika mereka merasa nyaman dengan pengaturan tata kelola perusahaan yang sehat. Tata kelola perusahaan yang baik juga meningkatkan ketahanan perusahaan dan ketahanan terhadap guncangan eksternal (Greuning, 2011: 37-38).

Surat edaran Bank Indonesia No. 12/13/DPbS tahun 2010menyatakan bahwa beberapa prinsip dasar Good Corporate Governance bagi perbankan syariahyaitu transparansi (transparency), akuntabilitas (accounttability), pertanggungjawaban (responsibility), profesional (professional) dan kewajaran (fairness). Untuk menganalisis pelaksanaandari kelima prinsip dasar GCG tersebut dalam suatu bank, maka bank perlu melakukan penilaian atas pelaksanaan GCG atauself assessment secara komprehensif.Menurut Tjondro, dkk (2011)Self assessment GCG merupakan penilaian terhadap pelaksanaan prinsipprinsip GCG, yang berisikan 11faktor penilaian pelaksanaan GCG yang diantaranya adalah 1) Pelaksanaan tugas dan tanggung jawab Dewan Komisaris, 2) Pelaksanaan tugas dan tanggung jawab Direksi, 3) Kelengkapan dan pelaksanaan tugas Komite, 4) Pelaksanaan tugas dan tanggung jawab Dewan Pengawas Syariah, 5) Pelaksanaan prinsip syariah dalam kegiatan penghimpunan 
dana dan penyaluran dana serta pelayanan jasa, 6) Penanganan benturan kepentingan, 7) Penerapan fungsi kepatuhan bank, 8) Penerapan fungsi audit intern, 9) Penerapan fungsi audit ekstern, 10) Batas maksimum penyaluran dana, 11) Transparansi kondisi keuangan dan non keuangan BUS, laporan pelaksanaan GCG serta pelaporan internal.Dalam pelaporan Self Assesment GCG, ada beberapa tahapan sampai pada hasil akhir penilaian komposit serta bagaimana perlakuan terhadap hasil pelaksanaan self assessment GCG bank yang berbeda dengan hasil pemeriksaan/pengawasan Bank Indonesia (Desiana, 2016).

Menurut Azis (2016) indikator pengukuran GCG adalah kepemilikan manajerial, kepemilikan institusional, komisaris independen dan komite audit.Dari beberapa indikator tersebut, penelitian ini akanmenggunakan Dewan Komisaris Independen sebagai proksi GCG. Dewan Komisaris Independen menurut UndangUndang No.40 tahun 2007 tentang Perseroan Terbatas, dewan komisaris adalah organ perseroan yang bertugas melakukan pengawasan secara umum dan atau khusus sesuai dengan anggaran dasar serta memberi nasihat kepada direksi. Dewan komisaris bertugas untuk mengawasi jalannya perusahaan berdasarkan prinsip-prinsip GCG.Selain itu, dewan komisaris memiliki kewajiban untuk mengawasi kinerja dewan direksi dan mengawasi pelaksanaan kebijakan dewan direksi. Sedangkan komisaris independen adalah anggota Dewan Komisaris yang tidak memiliki hubungan keuangan, kepengurusan, kepemilikan saham dan/atau hubungan keluarga dengan pemegang saham pengendali, anggota dewan komisaris lainnya dan/atau anggota direksi, atau hubungan keuangan dan/atau hubungan kepemilikan saham dengan BUS (Surat edaran Bank Indonesia No. 12/13/DPbS tahun 2010).

Dalam peraturan Bank Indonesia No. 8/4/PBI/2006 disebutkan bahwa jumlah anggota dewan komisaris minimal 3 orang atau paling banyak sama dengan jumlah dewan direksi. Dewan komisaris terdiri dari komisaris dan komisaris independen.Minimal 50\% dari jumlah anggota komisaris adalah komisaris independen.Dewan komisaris independen adalah anggota dewan komisaris yang terafiliasi dengan direksi, anggota dewan komisaris lainnya dan pemegang saham pengendali, serta bebas dari hubungan bisnis atau hubungan 
lainnya yang dapat mempengaruhi kemampuannya untuk bertindak independen atau bertindak semata-mata untuk kepentingan perseroan.Dewan komisaris independen berperan sebagai penyeimbang dalam pengambilan keputusan dewan komisaris (Aprianingsih, 2016).

\section{Profitabilitas}

Profitabilitas adalah kemampuan bank dalam menghasilkan keuntungan atau kemampuan bank dari berbagai sumber daya yang digunakan dalam kegiatan operasional.Sedangkan rasio profitabilitas juga dapat diartikan sebagai rasio yang mengukur kemampuan perusahaan menghasilkan keuntungan pada tingkat penjualan, aset dan modal saham tertentu (Temewu, dkk,2014).Menurut Yudiana (2013) rasio profitabilitas terdiri dari dua jenis rasio yang menunjukkan laba dalam hubungannya dengan penjualan dan rasio yang menunjukkan laba dalam hubungannya dengan investasi. Profitabilitas dalam hubungannya antara penjualan dengan laba dapat dibedakan sebagai berikut :

a. Gross Profit Margin (GPM)

Gross Profit Margin merupakan perbandingan penjualan bersih dikurangi harga pokok penjualan bersih atau rasio antara laba kotor dengan penjualan bersih.

b. Net Profit Margin (NPM)

Net Profit Margin yaitu margin laba bersih yang merupakan keuntungan penjualan setelah menghitung seluruh biaya dan pajak penghasilan.Margin ini merupakan perbandingan laba bersih setelah pajak penjualan.

c. Return on Investment (ROI)

Return on Investmen merupakan rasio yang membandingkan laba setelah pajak dengan total aktiva.

d. ROI dengan pendekatan Dupont

Pendekatan Dupont pertama kali digunakan oleh perusahaan Dupont untuk mengevaluasi efektivitas perusahaan, yaitu dengan mengalikan NPM dengan total assets turnover. 
e. Return on Equity (ROE)

Return on Equity yaitu rentabilitas modal sendiri yang digunakan untuk mengukur seberapa banyak keuntungan yang menjadi hak pemilik modal sendiri (Yudiana, 2013: 83).ROE adalah perbandingan antara laba bersih bank dengan modal sendiri.Rasio ini banyak diamati oleh para pemegang saham bank (baik pemegang saham pendiri maupun pemegang saham baru) serta para investor di pasar modal yang ingin membeli saham bank yang bersangkutan (jika bank tersebut sudah go public) (Dendawijaya, 2009: 119).

f. Rentabilitas Ekonomi (RE)

Rentabilitas ekonomi sering disebut juga dengan earning power yaitu mengukur kemampuan perusahaan dalam memperoleh laba usaha dengan aktiva yang digunakan untuk memperoleh laba tersebut.RE dihitung dengan membagi laba usaha (EBIT) dengan total aktiva (Yudiana, 2013: 84).

\section{Non Performing Financing (NPF)}

Risiko pembiayaan sering kali dikaitkan dengan risiko gagal bayar. Risiko ini mengacu pada potensi kerugian yang dihadapi bank ketika pembiayaan yang diberikannya macet.Debitur mengalami kondisi dimana dia tidak mampu memenuhi kewajiban mengembalikan modal yang diberikan oleh bank.Selain pengembalian modal, risiko ini juga mencakup ketidakmampuan debitur menyerahlan porsi keuntungan yang seharusnya diperoleh oleh bank dan telah diperjanjikan di awal.Selain risiko gagal bayar Bank Indonesia dalam PBI Nomor 13/23/PBI/2011 menggunakan istilah risiko kredit (Wahyudi, dkk, 2013: 91).

Risiko kredit adalah risiko akibat kegagalan debitur dan atau pihak lain dalam memenuhi kewajiban kepada bank. Pengukurannya dengan menggunakan rasio Non Performing Financing (NPF).Non Performing Financing (NPF) merupakan rasio yang dipergunakan untuk mengukur kemampuan bank dalam meng-cover risiko kegagalan pengembalian kredit oleh debitur.Non Performing Financing (NPF) dapat diukur melalui perbandingan antara jumlah pembiayaan bermasalah dengan total pembiayaan (Suhartatik dan Kusumaningtias, 2013).Non Performing Financing (NPF) merupakan istilah yang sama dengan Non Performing Loan 
(NPL) pada bank konvensional. Rasio NPL menunjukkan kemampuan manajemen bank dalam mengelola kredit bermasalah atas kredit yang telah diberikan bank. NPL merupakan presentase jumlah kredit bermasalah terhadap total kredit yang dikeluarkan oleh bank. Rasio NPL yang tinggi akan memperbesar biaya, sehingga berpotensi menyebabkan kerugian terhadap bank. Alasan ini yang menjadi dasar rasio NPL menjadi variabel negatif, karena semakin tinggi kredit bermasalah maka tinggi kemungkinan kerugian bank atau semakin rendah profitabilitas (Hermina, dkk, 2014).

Faktor penyebab munculnya NPF adalah deafault payment (kegagalan pembayaran) yang dilakukan kreditur kepada pemilik dana (debitur). Kredit bermasalah didefinisikan sebagai risiko yang dikaitkan dengan kemungkinan kegagalan klien membayar kewajibannya atau risiko dimana debitur tidak dapat melunasi hutangnya.Kriteria rasio NPF analog dengan NPL sesuai Peraturan Bank Indonesia No.17/11/PBI/2015 dibawah 5\% (Khatimah, 2009: 5).

Persyaratan yang ketat dalam kebijakan kredit akan mengurangi kemungkinan terjadinya kredit bermasalah, namun tidak akan menghilangkan timbulnya masalah penunggakan pembayaran. Kecenderungan kerugian yang timbul dari kredit yang disalurkan pada dasarnya dikarenakan kurangnya perhatian bank secara serius setelah kredit tersebut berjalan.Selain itu permasalahan sesungguhnya adalah masalah deteksi dini.Bagaimana suatu kredit yang mulai mengalami masalah dapat segera diketahui sehingga masih ada waktu untuk melakukan tindakan pencegahan dan perlindungan terhadap kerugian (Siamat, 2005: 359).

Dalam akuntansi, terdapat akun cadangan penyisihan piutang tak tertagih dan beban penghapusan piutang tak tertagih.Hal ini diistilahkan sebagai Penyisihan Penghapusan Aset Produktif (PPAP).PPAP merupakan cadangan (modal) yang harus dibentuk berdasarkan penggolongan kualitas pembiayaan.PBI Nomor 5/9/PBI/2003 mengatur tentang ketentuan besarnya cadangan yang harus dibuat.Fungsi utama pembentukan PPAP ini adalah untuk menghindarkan bank dari potensi kegagalan bisnis jika debitur benar-benar gagal bayar. Sebelum 
debitur gagal bayar, bank telah menyiapkan sejumlah modal yang dicadangkan untuk menghindari risiko yang lebih besar (Wahyudi, 2013: 119).

\section{Kerangka Penelitian}

Kerangka penelitian yang digunakan dalam penelitian ini adalah sebagai berikut :

\section{Gambar 1 \\ Kerangka Penelitian}

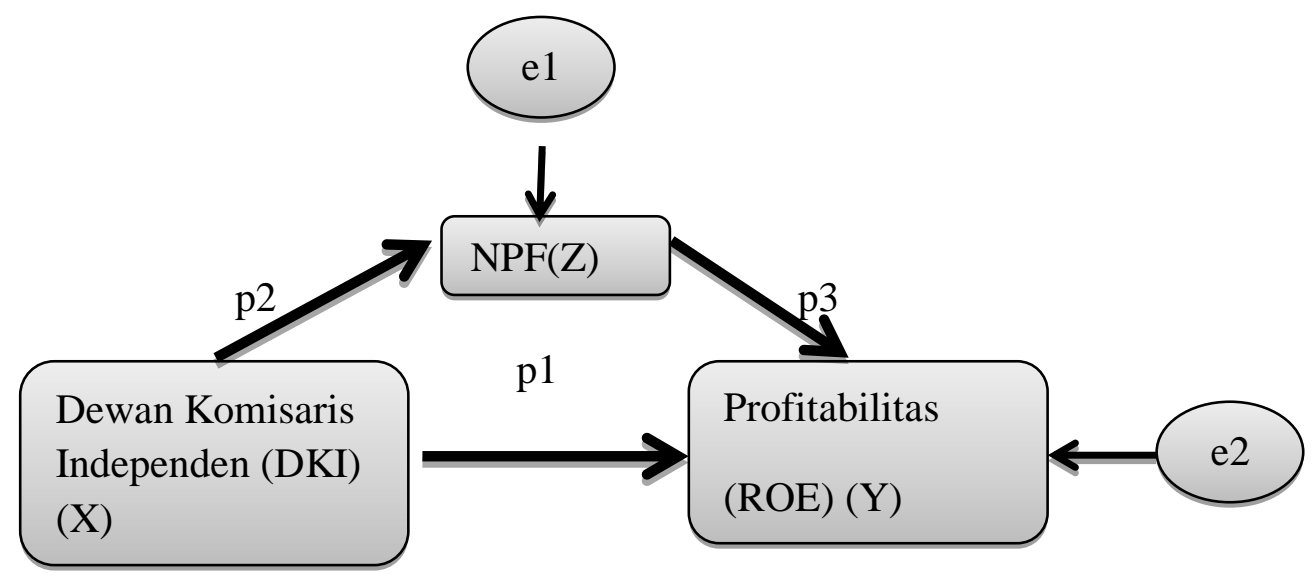

\section{Pengaruh Dewan Komisaris Independen terhadap Profitabilitas}

Wardani (2007) menyatakan bahwa komisaris independen dapat bertindak sebagai penengah dalam perselisihan yang terjadi di antara para manajer internal dan mengawasi kebijakan manajemen serta memberikan nasihat kepada manajemen. Komisaris independen merupakan posisi terbaik untuk melaksanakan fungsi monitoring agar tercipta perusahaan yang good corporate governance. Peran komisaris ini diharapkan akan meminimalkan permasalahan keagenan yang timbul antara dewan direksi dengan pemegang saham. Sehingga apabila semakin banyak komisaris independen, maka pengawasan akan semakin ketat danagency problem semakin kecil.

Semakin banyak jumlah dewan komisaris independen, maka semakin terlepas pula penyusunan laporan keuangan dari unsur kepentingan pribadi sehingga laporan keuangan dapat disusun sedemikian rupa dan mewakili kenyataan yang sesungguhnya terjadi. Semakin tinggi persentase dewan komisaris independen, 
maka diharapkan semakin tinggi pula kinerja karyawan yang nantinya akan meningkatkan profitabilitas perusahaan (Kusuma, 2015 ).

Hasil penelitian Rini(2012),Sanjaya \& Marsudi (2014), Agustiningsih (2016) dan Dzajilah (2016) menunjukkan bahwa Good Corporate Governance (GCG) yang di proyeksikan dengan dewan komisaris independen berpengaruh positif dan signifikan terhadap profitabilitas.Berdasarkan pada uraian di atas, maka hipotesis pertama (H1) dalam penelitian iniyaitu :

$\mathrm{H}_{1}$ :Dewan Komisaris Independen berpengaruh positif dan signifikan terhadap profitabilitas.

\section{Pengaruh Dewan Komisaris Independen terhadap Non Performing Financing (NPF)}

Dewan komisaris independen adalah anggota dewan komisaris yang terafiliasi dengan direksi, anggota dewan komisaris lainnya dan pemegang saham pengendali, serta bebas dari hubungan bisnis atau hubungan lainnya yang dapat mempengaruhi kemampuannya untuk bertindak independen atau bertindak semata-mata untuk kepentingan perseroan.Dewan komisaris independen berperan sebagai penyeimbang dalam pengambilan keputusan dewan komisaris (Aprianingsih, 2016).

Menurut Pathan, et al (2007), peran dewan komisaris independen sangat diperlukan untuk memastikan bahwa perusahaan telah melaksanakan kaidahkaidah corporate governance.Dewan komisaris independen juga memiliki peran sebagai penengah jika terjadi perselisihan di antara manajemen serta memberikan masukan-masukan demi kinerja lebih baik. Semakin banyak jumlah dewan komisaris independen dalam perusahaan akan mewujudkan good corporate governance yang berimbas pada kegiatan operasional yang baik termasuk dalam keputusan pemberian kredit/pembiayaan yang tepat sehingga dapat mengurangi tingkat NPL/NPF.Hipotesis kedua (H2) dalam penelitian ini adalah:

$\mathrm{H}_{2}$ :Dewan Komisaris Independen berpengaruh negatif dan signifikan terhadapNon Performing Financing (NPF). 


\section{Pengaruh Non Performing Financing (NPF) terhadap Profitabilitas}

Risiko pembiayaan adalah risiko akibat kegagalan debitur dan atau pihak lain dalam memenuhi kewajiban kepada bank. Pengukurannya dengan menggunakan rasio Non Performing Financing (NPF).Non Performing Financing (NPF) merupakan rasio yang dipergunakan untuk mengukur kemampuan bank dalam meng-cover risiko kegagalan pengembalian pembiayaan oleh debitur.Non Performing Financing (NPF) dapat diukur melalui perbandingan antara jumlah pembiayaan bermasalah dengan total pembiayaan (Suhartatik dan Kusumaningtias, 2013).

Non Performing Financing (NPF) merupakan istilah yang sama dengan Non Performing Loan (NPL) pada bank konvensional. Rasio NPL menunjukkan kemampuan manajemen bank dalam mengelola kredit/pembiayaan bermasalah atas kredit/pembiyaan yang telah diberikan bank (Hermina, dkk, 2014). NPL/NPF merupakan presentase jumlah kredit/pembiyaan bermasalah terhadap total kredit/pembiayaan yang dikeluarkan oleh bank. Rasio NPL/NPF yang tinggi akan memperbesar biaya, sehingga berpotensi menyebabkan kerugian terhadap bank. Alasan ini yang menjadi dasar peneliti menemukan rasio NPL/NPF menjadi variabel yang memiliki pengaruh negatif, karena semakin tinggi kredit/pembiyaan bermasalah maka kemungkinan kerugian bankakan semakin besar atau semakin rendah profitabilitas yang diperoleh bank(Hermina, dkk, 2014).Hasil penelitian Saputri \& Oetomo (2016) menunjukkan bahwa NPF memiliki pengaruh negatif dan signifikan terhadap profitabilitas.Berdasarkan uraian di atas maka hipotesis ketiga (H3) dalam penelitian yaitu :

$\mathrm{H}_{3}$ :Non Performing Financing (NPF) berpengaruh negatif dan signifikan terhadap profitabilitas

\section{Pengaruh Dewan Komisaris Independen terhadap Profitabilitas dengan Non Performing Financing (NPF) sebagai variabel intervening}

Mekanisme tata kelola yang efektif dalam perusahaan ditunjukkan melalui mekanisme monitoring internal ( komposisi dewan direksi, komposisi dewan komisaris, keberadaan dan efektivitas komite audit) dan mekanisme monitoring eksternal (proporsi komisaris independen, struktur kepemilikan, kualitas audit dan 
ancaman pengambialihan perusahaan) sehingga dapat mendorong peningkatan kinerja perusahaan tersebut (Setyawaty, 2016).Salah satu tugas atau peran dari dewan komisaris independen adalah mengawasi tata kelola perusahaan apakah sudah berjalan secara efektif atau belum serta sebagai penyeimbang dalam pengambilan keputusan dewan komisaris.Termasuk dalam hal pengambilan keputusan-keputusan yang mengandung risiko. Sehingga dengan adanya dewan komisaris independen maka risiko-risiko akan dapat dikurangi atau bahkan dihilangkan termasuk dalam hal pembiayaan bermasalah (NPF). Sehingga semakin banyak jumlah dewan komisaris independen maka akan semakin kecil tingkat NPF. Dengan tingkat NPF yang kecil maka akan berpengaruh terhadap tingkat profitabilitas bank. Berdasarkan pada uraian di atas makahipotesis keempat (H4) dalam penelitian ini yaitu :

$\mathrm{H}_{4}$ :Non Performing Financing (NPF) memediasi pengaruh Dewan Komisaris Independen(GCG) terhadap profitabilitas.

\section{Metode Penelitian}

\section{Jenis Penelitian}

Jenis penelitian ini adalah penelitian lapangan (field research) dengan pendekatan kuantitatif, yang pengukurannya menggunakan bentuk angka yang diperoleh dari laporan keuangan yang telah dipublikasikan oleh bank syariah , kemudian di analisis dengan menggunakan teori statistik. Jenis penelitian ini dipandang mampu memberikan informasi untuk melihat realita atau fenomena yang konkrit yang terjadi dalam objek penelitian (Alfianika, 2016: 29).

\section{Populasi dan Sampel}

Populasi yaitu wilayah generalisasi yang terdiri atas obyek atau subyek yang mempunyai kualitas dan karakteristik tertentu yang ditetapkan oleh peneliti untuk dipelajari dan kemudian ditarik kesimpulannya (Sugiyono, 2012: 117). Populasi yang digunakan dalam penelitian ini adalah Bank Umum Syariah yang terdaftar di Bank Indonesia periode 2011-2015 sebanyak 13 bank syariah.

Sampel adalah bagian dari jumlah dan karakteristik yang dimiliki oleh populasi (Sugiyono, 2012: 118).Teknik pengambilan sampel yang digunakan adalah Purposive Sampling.Metode purposive sampling yaitu teknik penentuan 
sampel dengan pertimbangan tertentu (Sugiyono, 2012: 122). Adapun beberapa pertimbangan yang digunakan penulis untuk memilih sampel yaitu :

a. Bank Umum Syariah yang terdaftar di Bank Indonesia periode tahun 20112015.

b. Bank Umum syariah yang menyajikan laporan keuangan tahunan yang telah diaudit dan dipublikasikan di website periode 2011-2015.

c. Data laporan yang di audit dan dipublikasikan memiliki kelengkapan data yang diperlukan untuk penelitian ini.

Setelah dilakukan purposive sampling, maka hanya ada 11 bank syariah yang memenuhi kriteria-kriteria tertentu yang dibutuhkan oleh penulis.Jadi sampel yang digunakan dalam penelitian ini sebanyak 11 bank syariah.

\section{Tehnik Pengumpulan Data}

Sumber data yang digunakan dalam penelitian ini adalah sumber data sekunder berupa data time series dan cross section yaitu laporan keuangan tahunan, laporan pengungkapan GCG yang telah dipublikasikan oleh bank umum syariah dari tahun 2011-2015.Sumber data lain diperoleh dengan membaca dan mempelajari serta menganalisis literature yang bersumber dari buku, jurnal, laporan penelitian, artikel dan perangkat lain yang berkaitan dengan permasalahan yang diteliti. Hal ini dilakukan untuk membantu penulis memecahkan masalah yang diteliti dan hasilnya akan dijadikan sebagai bahan perbandingan.

\section{Skala Pengukuran}

Dalam penelitian ini, penulis menggunakan skala rasio.Data rasio adalah data yang memiliki titik nol absolut. Dengan kata lain rasio memiliki semua ciri dari data interval dan ditambah pula mempunyai titik nol absolut sebagai titik permulaan.Dalam penelitian ini menggunakan 3 variabel yang terbagi atas satu variabel terikat (variabel dependen), satu variabel bebas (variabel independen) dan satu variabel intervening, yang meliputi tingkat profitabilitas yang diukur dengan ROE (Y), Dewan Komisaris Independen (X) dan NPF (Z). 


\section{Definisi Konsep dan Operasional}

Dewan Komisaris Independenadalah anggota dewan komisaris yang terafiliasi dengan direksi, anggota dewan komisaris lainnya dan pemegang saham pengendali, serta bebas dari hubungan bisnis atau hubungan lainnya yang dapat mempengaruhi kemampuannya untuk bertindak independen atau bertindak semata-mata untuk kepentingan perseroan.Dewan komisaris independen berperan sebagai penyeimbang dalam pengambilan keputusan dewan komisaris (Aprianingsih, 2016; Endraswati, dkk, 2014).

$$
\text { Dewan Komisaris Independen }=\frac{\text { Jumlah Komisaris Independen }}{\text { Jumlah Komisaris }}
$$

Return on Equityyaitu perbandingan antara laba bersih bank dengan modal sendiri (Dendawijaya, 2009 : 118; Endraswati, $2016: 120$ ).

$$
R O E=\frac{\text { Laba Bersih }}{\text { Modal Sendiri }} \times 100 \%
$$

Non Performing Financingmerupakan istilah yang sama dengan Non Performing Loan (NPL) pada bank konvensional. NPL merupakan rasio yang digunakan untuk mengukur kemampuan bank dalam mengcover risiko kegagalan pengembalian kredit oleh debitur (Suhartik \& Kusumaningtyas, 2013).Adapun rumus yang digunakan untuk mengukur Non Performing Financing (NPF), yaitu:

$$
N P F=\frac{\text { Jumlah pembiayaan bermasalah }}{\text { Total pembiayaan }} \times 100 \%
$$

\section{Hasil Penelitian dan Pembahasan}

\section{Uji Stasioneritas}

Uji stasioneritas ini digunakan untuk menganalisis data time series atau cross section untuk melihat ada tidaknya unit root yang terkandung diantara variabel sehingga hubungan antar variabel dalam persamaan menjadi valid. Dalam pengujian stasioner menggunakan Augment Dicky Fuller Unit Root Tet (ADF Test) terhadap variabel-variabel independen. Jika nilai probabilitasnya menunjukkan pada level dasar yakni $<\alpha=5 \%$ maka tidak terjadi unit root. Sebaliknya jika nilai probabilitasnya $>\alpha=5 \%$ maka terjadi unit root yang berarti bahwa data yang akan diolah sudah stasioner (Purba, 2014:19). 
Tabel 1.Uji Stasioner

\begin{tabular}{|c|c|c|c|c|c|c|}
\hline \multirow[t]{2}{*}{ Variabel } & \multirow{2}{*}{$\begin{array}{l}\text { ADF } \\
\text { Statistic }\end{array}$} & \multicolumn{3}{|c|}{ Nilai Kritis Mc Kinnon } & \multirow{2}{*}{$\begin{array}{l}\text { Prob } \\
\text { ADF } \\
5 \%\end{array}$} & \multirow[t]{2}{*}{ Ket } \\
\hline & & $1 \%$ & $5 \%$ & $10 \%$ & & \\
\hline DKI & -6.534350 & -3.562669 & -2.918778 & -2.597285 & 0.0000 & Stasioner \\
\hline NPF & -3.101678 & -3.560019 & -2.917650 & -2.596689 & 0.0324 & Stasioner \\
\hline ROE & -9.249980 & -3.560019 & -2.917650 & -2.596689 & 0.0000 & Stasioner \\
\hline
\end{tabular}

Sumber : hasil olah Eviews7

Dalam pengujian Unit Root di tingkat $1^{\text {st }}$ difference, ADF telah menunjukkan bahwa data yang diolah sudah stasioner.Hal ini dapat dilihat pada nilai absolute statistic ADF yang lebih kecil dari McKinnon Critical Value pada nilai kritis 1\%, $5 \%$, dan 10\%. Selain itu, pada nilai Prob statistik ADF menunjukkan angka yang lebih kecil dari $\alpha$ 0,05 McKinnon. Dengan demikian maka dapat dinyatakan bahwa seluruh variabel dalam penelitian ini telah stasioner di tingkat $1^{\text {st }}$ difference.

\section{Uji Deskriptif Statistik}

Uji deskriptif dilakukan untuk menunjukkan jumlah data $(\mathrm{N})$ yang digunakan dalam penelitian ini, nilai maksimum, nilai minimum, nilai rata-rata (mean) dan standar deviasi dari masing-masing variabel. Hasil perhitungan statistik deskriptif adalah sebagai berikut :

Tabel 2.Hasil Uji Deskriptif

\begin{tabular}{|l|r|r|r|r|r|}
\hline \multicolumn{7}{|c|}{ Descriptive Statistics } \\
\hline DKI & N & \multicolumn{1}{|c|}{ Minimum } & Maximum & \multicolumn{1}{c|}{ Mean } & \multicolumn{1}{c|}{ Std. Deviation } \\
NPF & 55 & $20.00 \%$ & $100.00 \%$ & $64.0624 \%$ & $17.47089 \%$ \\
ROE & 55 & $0.00 \%$ & $35.15 \%$ & $3.8355 \%$ & $4.82266 \%$ \\
Valid N & 55 & $-32.04 \%$ & $57.98 \%$ & $6.1858 \%$ & $11.27821 \%$ \\
(listwise) & 55 & & & & \\
\hline
\end{tabular}

Sumber :data sekunder yang diolah, 2017

Dari tabel di atas dapat diketahui bahwa nilai terendah (minimum) pada rasio DKI adalah 20,00 yang berasal dari BJB Syariah pada tahun 2012. Sedangkan untuk rasio DKI nilai tertinggi (maksimum) adalah 100,00 berasal dari beberapa bank salah satunya berasal dari Bank Mega Syariah pada tahun 2011. Nilai rata-rata (mean) DKI sebesar 64,0624 dan untuk standar deviasinya adalah 17,47089. Dengan melihat nilai rata-rata (mean) pada DKI, maka dapat 
disimpulkan bahwa secara statistik nilai rata-rata DKI pada Bank Umum Syariah di Indonesia telah memenuhi syarat atau peraturan Bank Indonesia yang menyatakan bahwa minimal 50\% dari jumlah anggota dewan komisaris adalah komisaris independen.

Data rasio NPF memiliki nilai terendah (minimum) sebesar $0,00 \%$ yang berasal dari Maybank Syariah pada tahun 2011, sedangkan untuk nilai tertinggi (maksimum) sebesar 35,15\% yang berasal dari Maybank Syariah pada tahun 2015. Nilai rata-rata (mean) untuk rasio NPF sebesar 3,8355\% dan standar deviasi sebesar 4,82266\%. Dari nilai rata-rata (mean) rasio NPF maka dapat disimpulkan bahwa secara statistic nilai rata-rata (mean) NPF pada Bank Umum Syariah di Indonesia tahun 2011-2015 berada di bawah 5\%. Hal ini menunjukkan NPF pada Bank Umum Syariah telah memenuhi peraturan Bank Indonesia yang masuk dalam kategori sehat adalah bank yang memiliki nilai NPF minimal di bawah 5\%.

Data rasio ROE nilai terendah (minimum) sebesar $-32,04 \%$ yang berasal dari Maybank Syariah pada tahun 2015, sedangkan untuk nilai tertinggi (maksimum) sebesar 57,98\% yang berasal dari Bank Mandiri Syariah pada tahun 2012. Nilai rata-rata (mean) rasio ROE adalah $6,1858 \%$ dan standar deviasinya adalah $11,27821 \%$.

\section{Uji Asumsi Klasik}

\section{Uji Multikolinieritas}

Uji multikolinieritas bertujuan untuk menguji apakah pada model regresi ditemukan adanya korelasi antar variabel bebas (independen).Untuk melihat ada atau tidaknya multikolonieritas dapat dideteksi dengan cara melihat nilai tolerance dan variance inflation factor (VIF). Nilai cutoff yang umum dipakai sebagai standar yang menunjukkan tidak terjadi multikolonieritas adalah nilai tolerance di atas 0,10 atau sama dengan nilai VIF di bawah 10 (Ghozali, 2013 : 106). Hasil uji multikolonieritas antar variabel dapat dilihat pada tabel di bawah ini. 
Tabel 3.Hasil Uji Multikolonieritas

Persamaan 2

Coefficients $^{\mathbf{a}}$
\begin{tabular}{|l|r|r|}
\hline \multirow{2}{*}{ Model } & \multicolumn{2}{|c|}{ Collinearity Statistics } \\
\cline { 2 - 3 } & Tolerance & \multicolumn{1}{|c|}{ VIF } \\
\hline (Constant) & & \\
1 DKI & .994 & 1.006 \\
NPF & .994 & 1.006 \\
\hline
\end{tabular}
a. Dependent Variable: ROE

Sumber :data sekunder yang diolah, 2017

Berdasarkan tabel di atas maka dapat diketahui bahwa nilai tolerance dan VIF masing-masing variabel penelitian adalah nilai tolerance untuk variabel DKI dan NPF sebesar 0,994>0,10 yang berarti tidak ada korelasi antar variabel independen yang nilainya lebih dari $95 \%$. Sedangkan nilai VIF sebesar $1,006<10$, sehingga dapat disimpulkan bahwa variabel DKIdan NPF dinyatakan tidak terjadi gejala multikolonieritas.

\section{Uji Autokorelasi}

Uji autokorelasi bertujuan menguji apakah dalam model regresi linier ada korelasi antara kesalahan pengganggu pada periode $\mathrm{t}$ dengan kesalahan pengganggu pada periode t-1 (sebelumnya).Jika terjadi korelasi, maka dinamakan ada masalah autokorelasi.Model regresi yang baik adalah regresi yang bebas dari autokorelasi.Untuk mengetahui ada atau tidaknya autokorelasi dalam suatu model regresi dapat dilakukan melalui beberapa model pengujian. Dalam penelitian ini menggunakan pengujian Durbin Watson (Uji DW) (Ghozali, 2013 : 110). Hasil pengujian autokorelasi dalam penelitian ini sebagai berikut :

Tabel 4.Hasil Uji Durbin Watson

\begin{tabular}{|c|c|c|c|c|}
\hline Persamaan & DU & $\begin{array}{c}\text { Durbin- } \\
\text { Watson }\end{array}$ & 4-DU & Keterangan \\
\hline 1 & 1,585 & 1,982 & 2,415 & $\begin{array}{c}\text { Tidak ada } \\
\text { autokorelasi }\end{array}$ \\
\hline 2 & 1,628 & 1,940 & 2,372 & $\begin{array}{c}\text { Tidak ada } \\
\text { autokorelasi }\end{array}$ \\
\hline
\end{tabular}

Sumber : Output SPSS 21, data sekunder yang diolah, 2017

Hasil uji Durbin-Watson (DW) pada tabel di atas menunjukkan bahwa pada persamaan 1 dan 2 memiliki nilai DW yang lebih besar dari nilai DU dan juga lebih kecil dari nilai 4-DU. Sehingga dapat disimpulkan bahwa pada persamaan 1 dan persamaan 2 tidak terdapat autokorelasi. 


\section{Uji Heteroskedastisitas}

Uji heteroskedastisitas bertujuan untuk menguji apakah dalam model regresi terjadi ketidaksamaan varians dari residu/pengamatan ke yang lain tetap, maka disebut homokedastisitas dan jika berbeda disebut heterokedastisitas. Model regresi yang baik adalah yang homokedastisitas atau tidak terjadi heteroskedastisitas (Ghozali, 2013: 139).Uji statistik yang digunakan untuk mendeteksi ada tidaknya heterokedastisitas yaitu uji park. Berikut ini hasil uji park :

\section{Tabel 5.Hasil Uji Park Persamaan 1}

\begin{tabular}{|c|c|c|c|c|c|}
\hline \multicolumn{6}{|c|}{ Coefficients $^{\mathrm{a}}$} \\
\hline \multirow[t]{2}{*}{ Model } & \multicolumn{2}{|c|}{ Unstandardized Coefficients } & Standardized & $\mathrm{T}$ & Sig. \\
\hline & B & Std. Error & Beta & & \\
\hline (Constant) & -2.799 & 1.385 & & -2.021 & .049 \\
\hline I'LNDKI1@ & .440 & 1.437 & 044 & .306 & .761 \\
\hline
\end{tabular}

Sumber :data sekunder yang diolah, 2017

Berdasarkan hasil tampilan ouput SPSS memberikan koefisien parameter untuk variabel independen tidak ada yang signifikan, maka dapat disimpulkan bahwa data model regresi dalam penelitian ini tidak terdapat heteroskedastisitas.

\section{Tabel 6.Hasil Uji Park}

\section{Persamaan 2}

\begin{tabular}{|c|c|c|c|c|c|}
\hline \multicolumn{6}{|c|}{ Coefficients $^{\mathrm{a}}$} \\
\hline \multirow[t]{2}{*}{ Model } & \multicolumn{2}{|c|}{$\begin{array}{l}\text { Unstandardized } \\
\text { Coefficients } \\
\end{array}$} & \multirow{2}{*}{$\begin{array}{c}\begin{array}{l}\text { Standardized } \\
\text { Coefficients }\end{array} \\
\text { Beta }\end{array}$} & \multirow[t]{2}{*}{$\mathrm{T}$} & \multirow[t]{2}{*}{ Sig. } \\
\hline & B & Std. Error & & & \\
\hline (Constant) & -1.471 & 3.707 & & -.397 & .694 \\
\hline 1.LNDKI2@ & -.002 & .941 & .000 & -.002 & .998 \\
\hline LNNPF2@ & .103 & .254 & .063 & .406 & .687 \\
\hline
\end{tabular}

Sumber :data sekunder yang diolah, 2017

Berdasarkan hasil tampilan ouput SPSS memberikan koefisien parameter untuk variabel independen tidak ada yang signifikan, maka dapat disimpulkan bahwa data model regresi dalam penelitian ini tidak terdapat heteroskedastisitas.

\section{Uji Normalitas}

Uji normalitas bertujuan untuk menguji apakah dalam model regresi, variabel pengganggu atau residual memiliki distribusi normal.Model regresi yang baik adalah model yang memiliki distribusi data normal atau mendekati normal. 
Penelitian ini menggunakan Kolmogorov Sminof (K-S) test untuk mengetahui normalitas data dengan melihat nilai Asymp. Sig. (2 tailed), apabila nilainya lebih dari 5\% maka residual terdistribusi normal (Ghozali, 2013: 165). Hasil uji normalitas dalam penelitian ini sebagai berikut :

\section{Tabel 7.Hasil Uji Normalitas \\ Persamaan 1}

\begin{tabular}{|ll|r|}
\hline \multicolumn{2}{|c|}{ One-Sample Kolmogorov-Smirnov Test } \\
\hline $\mathrm{N}$ & & $\begin{array}{c}\text { Unstandardized } \\
\text { Residual }\end{array}$ \\
Normal Parameters ${ }^{\mathrm{a}, \mathrm{b}}$ & Mean & 50 \\
& Std. Deviation & .0000000 \\
Most Extreme Differences & Absolute & 2.57412015 \\
& Positive & .102 \\
Kolmogorov-Smirnov Z & Negative & .066 \\
Asymp. Sig. (2-tailed) & & -.102 \\
a. Test distribution is Normal. & & .720 \\
b. Calculated from data. & & .678 \\
\hline
\end{tabular}

Berdasarkan pada tabel di atas, dapat diketahui bahwa nilai Asymp. Sig. (2tailed) sebesar 0,678 yang menunjukkan nilai signifikansi lebih dari 0,05. Sehingga dapat disimpulkan bahwa pada persamaan 1 data terdistribusi secara normal.

Tabel 8.Hasil Uji Normalitas

Persamaan 2

\begin{tabular}{|c|c|c|}
\hline \multicolumn{3}{|c|}{ One-Sample Kolmogorov-Smirnov Test } \\
\hline & & $\begin{array}{l}\text { Unstandardized } \\
\text { Residual }\end{array}$ \\
\hline $\begin{array}{l}\text { N } \\
\text { Normal Parameters }{ }^{\mathrm{a}, \mathrm{b}} \\
\text { Most Extreme Differences } \\
\text { Kolmogorov-Smirnov Z } \\
\text { Asymp. Sig. (2-tailed) }\end{array}$ & $\begin{array}{l}\text { Mean } \\
\text { Std. Deviation } \\
\text { Absolute } \\
\text { Positive } \\
\text { Negative }\end{array}$ & $\begin{array}{r}50 \\
.0000000 \\
.84775812 \\
.085 \\
.085 \\
-.068 \\
.602 \\
.862\end{array}$ \\
\hline
\end{tabular}

a. Test distribution is Normal.

b. Calculated from data.

Sumber : Output SPSS 21, data sekunder yang diolah, 2017

Berdasarkan pada tabel di atas, dapat diketahui bahwa nilai Asymp. Sig. (2tailed) sebesar 0,862 yang menunjukkan nilai signifikansi lebih dari 0,05. Sehingga dapat disimpulkan bahwa pada persamaan 2 data terdistribusi secara normal. 


\section{Uji Hipotesis}

\section{Analisis Jalur atau Path Analysis}

Analisis jalur atau path analysisdigunakan untuk menganalisis pengaruh Dewan Komisaris Independen terhadap profitabilitas dengan Non Performing Financing (NPF) sebagai variabel intervening (pemediasi).Berikut merupakan perhitungan analisis jalur atau path analysis dalam penelitian ini.

\section{Tabel 9.Hasil Uji Coefficient}

Persamaan 1

\begin{tabular}{|c|c|c|c|c|c|}
\hline \multicolumn{6}{|c|}{ Coefficients ${ }^{\mathrm{a}}$} \\
\hline \multirow[t]{2}{*}{ Model } & \multicolumn{2}{|c|}{ Unstandardized Coefficients } & Standardized & \multirow[t]{2}{*}{$\mathrm{T}$} & \multirow[t]{2}{*}{ Sig. } \\
\hline & $\mathrm{B}$ & Std. Error & Beta & & \\
\hline (Constant) & 1.219 & .454 & & 2.684 & .010 \\
\hline${ }^{1}$ LNDKI1@ & -1.048 & .471 & -.306 & -2.224 & .031 \\
\hline
\end{tabular}

Sumber :data sekunder yang diolah, 2017

\section{Tabel 10.Hasil Uji Coefficient \\ Persamaan 2}

\begin{tabular}{|c|c|c|c|c|c|c|}
\hline \multicolumn{7}{|c|}{ Coefficients $^{\mathrm{a}}$} \\
\hline \multirow{2}{*}{\multicolumn{2}{|c|}{ Model }} & \multicolumn{2}{|c|}{$\begin{array}{l}\text { Unstandardized } \\
\text { Coefficients }\end{array}$} & \multirow{2}{*}{$\begin{array}{c}\begin{array}{c}\text { Standardized } \\
\text { Coefficients }\end{array} \\
\text { Beta }\end{array}$} & \multirow[t]{2}{*}{$\mathrm{T}$} & \multirow[t]{2}{*}{ Sig. } \\
\hline & & B & Std. Error & & & \\
\hline \multirow{3}{*}{1} & (Constant) & -2.196 & 1.891 & & -1.162 & .252 \\
\hline & LNDKI2@ & .971 & .480 & .302 & 2.023 & .049 \\
\hline & LNNPF2@ & .022 & .129 & .026 & .171 & .865 \\
\hline
\end{tabular}

a. Dependent Variable: LNROE2@

Sumber :data sekunder yang diolah, 2017

Dari hasil output SPSS di atas memberikan nilai unstandardized betaDKI pada persamaan 1 sebesar -1,048 dan signifikan pada 0,031 yang berarti DKI mempengaruhi NPF. Nilai koefisien unstandardized beta -1,048 merupakan nilai path atau jalur p2. Pada output SPSS persamaan 2 nilai unstandardized beta untuk DKI 0,971 dan signifikan pada 0,049, artinya DKI berpengaruh positif signifikan terhadap profitabilitas (ROE). Nilai koefisien ini merupakan nilai path atau jalur p1. Sedangakan nilai unstandardized NPF adalah 0,022 dan tidak signifikan pada 0,865, artinya NPF tidak berpengaruh terhadap profitabilitas (ROE) .Nilai koefisien ini merupakan nilai path atau jalur p3. 
Pengaruh langsung DKIke ROE $\quad=0,971$

Pengaruh tak langsung DKI ke NPF ke ROE $=-1,048 \times 0,022$

Total pengaruh (DKIke ROE) = $\quad=0,947944$

Sebelum mendapatkan $\mathrm{t}$ hitung untuk mengetahui apakah ada pengaruh mediasi atau tidak maka peneliti harus menghitung standar error terlebih dahulu.

$$
\begin{aligned}
& \square \square 2 \square 3=\sqrt{ } \square 3^{2} \square \square 2^{2}+\square 2^{2} \square 3^{2}+\square \square 2^{2} \square \square 3^{2} \\
& \square \square 2 \square 3=\sqrt{ } 0,022^{2} 0,471^{2}+1,048^{2} 0,129^{2}+0,471^{2} 0,129^{2} \\
& \square \square 2 \square 3=\sqrt{ } 0,02199 \\
& \square \square 2 \square 3=0,1483
\end{aligned}
$$

Keterangan :

Sp2 dan Sp3 didapat dari Standar Error pada Unstandardized Coefficients pada $\mathrm{p} 2$ dan $\mathrm{p} 3$.

Berdasarkan hasil Sp2p3 peneliti dapat menghitung nilai t statistik pengaruh mediasi, sebagai berikut :

$$
\square=\frac{\square 2 \square 3}{\square \square 2 \square 3}=\frac{-0,0230}{0,1483}=-0,155
$$

Berdasarkan hasil penelitian dengan menggunakan analisis jalur atau path analysis dapat disimpulkan bahwa NPF tidak dapat berperan sebagai variabel intervening antara DKI dan profitabilitas (ROE). Hal ini dikarenakan nilai t hitung $=-0,155$ lebih kecil dari $\mathrm{t}$ tabel dengan tingkat signifikansi 0,05 yaitu 2,011. Hasil ini menunjukkan bahwa pengaruh DKI terhadap profitabilitas (ROE) perbankan syariah adalah secara langsung tidak melalui NPF.

Berdasarkan analisis data yang telah dilakukan oleh peneliti, hasil dari uji hipotesis dalam penelitian ini dapat menunjukkan bahwa variabel DKI berpengaruh positif dan signifikan terhadap profitabilitas (ROE) sehingga $\mathrm{H}_{1}$ diterima.Hal ini dapat dilihat dari hasil uji output SPSS, dimana DKI memiliki nilai signifikansi 0,049 lebih kecil dari 0,05 atau 5\%. Ini menunjukkan bahwa ketika DKI meningkat maka profitabilitas (ROE) juga akan meningkat. Hal ini sesuai dengan penelitian yang dilakukan oleh Agustiningsih (2016), Rini (2012), Nugrahani \& Nugroho (2010), Dzajilah (2016), Sanjaya \& Marsudi (2014), Endri (2012) yang menunjukkan bahwa Good Corporate Governance (GCG) yang di 
proyeksikan dengan dewan komisaris independen berpengaruh positif dan signifikan terhadap profitabilitas.

Hasil penelitian ini berbeda dengan penelitian yang dilakukan oleh Tjandra (2015) yang menunjukkan bahwa dewan komisaris independen berpengaruh negatif dan signifikan terhadap profitabilitas. Hasil ini juga berbeda dengan penelitian yang dilakukan oleh Septiana, dkk (2016), Raja (2016), Puspitasari \& Ernawati (2010), Putra \& Nuzula (2017), Aprinita (2016) yang menunjukkan bahwa dewan komisaris independen tidak berpengaruh terhadap profitabilitas.

Hasil penelitian ini juga menunjukkan bahwa variabel DKI berpengaruh secara negatif dan signifikan terhadap NPF sehingga $\mathrm{H}_{2}$ diterima. Hal ini dapat dilihat dari hasil uji output SPSS yang menyatakan bahwa variabel DKI memiliki nilai signifikansi 0,031 lebih kecil dari 0,05 atau 5\%. Ini menunjukkan bahwa adanya pengaruh yang signifikan dari variabel DKI terhadap NPF.Sehingga dapat dinyatakan bahwa terdapat pengaruh negatif dan signifikan antara DKI dengan NPF.Hasil ini menyimpulkan bahwa ketika DKI tinggi menunjukkan bahwa perbankan telah melakukan tata kelola perusahan yang baik sehingga dapat meminimalisir atau mengurangi NPF.

Hasil ini mendukung penelitian yang dilakukan Wardani (2007), Nora \& Veronica (2008), Dianita (2014) yang menunjukkan bahwa GCG yang diproyeksikan dengan dewan komisaris independen berpengaruh negatif dan signifikan terhadap NPL.Namun hasil penelitian ini tidak mendukung penelitian yang dilakukan oleh Mubarok (2016) yang menunjukkan bahwa dewan komisaris independen berpengaruh positif dan tidak signifikan terhadap NPF.Selain itu,hasil penelitian ini berbeda dengan penelitian yang dilakukan oleh Mirawati \& Halini (2014) yang menunjukkan bahwa dewan komisaris independen tidak berpengaruh terhadap NPL.

Hasil penelitian ini menunjukkan bahwa NPF berpengaruh positif dan tidak signifikan terhadap ROE.Hal ini dapat dilihat dari hasil uji output SPSS yang menyatakan bahwa variabel NPF memiliki nilai signifikansi 0,865 dimana nilai tersebutberada jauh diatas 0,05 atau 5\%.Ini menunjukkan bahwa tidak ada 
pengaruh yang signifikan dari variabel NPF terhadap profitabilitas (ROE).Sehingga $\mathrm{H}_{3}$ yang menyatakan NPF berpengaruh negatif dan signifikan terhadap profitabilitas (ROE) ditolak.Hasil ini menyimpulkan bahwa tinggi rendahnya NPF tidak akan mempengaruhi profitabilitas (ROE).Hal tersebut dikarenakan status risiko pembiayaan yang awalnyaberstatus kurang lancar dan diragukan dapat berubah menjadi macet.Status perubahan risiko ini dikarenakan kemampuan nasabah yang benar-benar tidak mampu lagi untuk membayar.Selain itu bisa dikarenakan pihak manajemen yang kurang ketat dalam mengelola risiko pembiayaan, sehingga terjadi pembiayaan macet atau gagal bayar yang menyebabkan perusahaan tidak memperoleh keuntungan atau profitabilitas. Oleh karena itu risiko pembiayaan tidak berpengaruh terhadap profitabilitas (ROE).Hasil penelitian ini mendukung penelitian yang dilakukan oleh Hermina,dkk (2014) dan Santoso (2016) menunjukkan bahwa NPL tidak berpengaruh terhadap profitabilitas.Hasil penelitian ini berbeda dengan penelitian yang dilakukan oleh Siswanti (2016) dan Ferdyant, dkk (2014) yang menunjukkan bahwa NPF berpengaruh negatif dan signifikan terhadap profitabilitas.

\section{SIMPULAN}

Berdasarkan hasil penelitian yang telah dilakukan maka dapat disimpulkan bahwa terdapat pengaruh positif dan signifikan pada variabel DKI terhadap profitabilitas (ROE). Hal ini menunjukkan bahwa ketika DKI meningkat maka profitabilits (ROE) juga akan meningkat.Hasil penelitian ini juga menunjukkan bahwa terdapat pengaruh negatif dan signifikan pada variabel DKI terhadap NPF. Hal ini menunjukkan bahwa ketika DKI meningkat maka NPF akan menurun. Namun, hasil penelitian ini menunjukkan terdapat pengaruh positif dan tidak signifikan pengaruh variabel NPF terhadap ROE. Hal ini menunjukkan bahwa tinggi rendahnya NPF tidak akan mempengaruhi profitabilitas (ROE).Hasil penelitian ini juga menunjukkan bahwa NPF tidak dapat berperan sebagai variabel intervening atau tidak mampu memediasi pengaruh antara DKI dan profitabilitas (ROE). Dengan kata lain, pengaruh DKI terhadap profitabilitas adalah langsung, tidak melalui NPF terlebih dahulu. 


\section{DAFTAR PUSTAKA}

Agustiningsih, S. Wahyu. 2016. Pengaruh Penerapan Corporate Governance terhadap Kinerja Keuangan Perusahaan di Indonesia. Jurnal Akuntansi \& Bisnis 16(1)

Alfianika, N. 2016.Buku Ajar Metode Penelitian Pengajaran Bahasa Indonesia.Yogyakarta : Deepublish

Aprianingsih, Astri. 2016. Pengaruh Penerapan GCG, Struktur Kepemilikan dan Ukuran Perusahaan terhadap Kinerja Keuangan Perbankan yang terdaftar di BEI Periode 2011-2014. Skripsi : Fakultas Ekonomi Universitas Negeri Yogya

Aprinita, B.S. 2016. Pengaruh GCG terhadap Kinerja Keuangan pada Perusahaan Sektor Consumer Goods yang terdaftar di BEI tahun 2012-2014.Jurnal Bisnis dan Manajemen

Aziz, Sarfia Abdul. 2016. Pengaruh Corporate Governance terhadap Nilai Perusahaan dengan Kinerja Keuangan sebagai Variabel Intervening pada Perusahaan Manufaktur yang terdaftar di BEI Tahun 2010-2014. Skripsi : Fakultas Ekonomi dan Bisnis Islam UIN Alauddin Makassar

Dendawijaya, Lukman. 2009. Manajemen Perbankan. Jakarta : Ghalia Indonesia

Desiana, Lidia. 2016. Pengaruh Good Corporate Governance terhadap Profitabilitas (ROE) pada Bank Umum Syariah di Indonesia Periode 20102015. I-Finance 2 (2). Desember 2016

Dianita, Mirna. 2014. Pengaruh Mekanisme Corporate Governance terhadap Kinerja Keuangan Perbankan. Jurnal Ilmiah Akuntansi \& Humanika 4(1)

Dzajilah, Rachma. 2016. Pengaruh Mekanisme GCG \& Pengungkapan CSR terhadap Kinerja Keuangan. Jurnal Ilmu dan Riset Akuntansi5(10)

Endraswati, Hikmah,. Suhardjanto, Djoko., Krismiaji. 2014. Board of Directors and Remuneration in Indonesian Banking. GSTF International Journal on Business Review (GBR), Vol. 3 No.3

Endraswati, Hikmah. 2016. Woman As Board of Commisionerdan Kinerja Perbankan Syariah di Indonesia. Salatiga : Phoenix Publisher

Endri. 2012. Pengaruh Mekanisme Corporate Governance terhadap Kinerja Profitabilitas Perbankan Syariah di Indonesia. Jurnal Keuangan \& Perbankan, 16 (2): 264-274

Ferdyant, Ferly dkk. 2014. Pengaruh Kualitas Penerapan Good Corporate Governance dan Risiko Pembiayaan terhadap Profitabilitas Perbankan Syariah. Jurnal Dinamika Akuntansi dan Bisnis 1(2): 134-149. Jakarta : Universitas Negeri Jakarta 
Ghozalli, Imam. 2013. Aplikasi Analisis Multivariate dengan Program IBM SPSS 21 Update PLS Regresi. Semarang : Badan Penerbit Universitas Diponegoro Greuning, Hennie van. 2011. Analisis Risiko Perbankan. Jakarta : Salemba Empat Hermina, Rida., Suprianto, Edy . 2014. Analisis Pengaruh CAR, NPL, LDR, dan BOPO terhadap Profitabilitas (ROE) pada Bank Umum Syariah. Jurnal Akuntansi Indonesia3(2) Juli 2014.Semarang : Fakultas Ekonomi Universitas Islam Sultan Agung

Indroes, N. Ferry. 2011. Manajemen Risiko Perbankan. Jakarta : PT Raja Grafindo Persada

Khatimah, H. 2009, Maret. Analisis Faktor-Faktor yang Mempengaruhi Penyaluran Dana Perbankan di Indonesia Sebelum dan Sesudah Kebijakan Akselerasi Perbankan Syariah Tahun 2007/2008.Jurnal Optimal, 3(1): 5

Kusuma, Eriza Mayang., Supatmi. 2015. Hubungan Mekanisme Corporate Governance dan Kinerja keuangan Bank Pembiayaan Rakyat Syariah. Salatiga : Fakultas Ekonomi dan Bisnis UKSW

Muhammad. 2013. Manajemen Keuangan Syariah. Yogyakarta

Nora, Eliyana \& Veronica, Sylvia. 2008. Pengaruh Ukuran Dewan Komisaris Independen \& Kepemilikan Institusional terhadap NPL. Jurnal Ekonomi \& Bisnis 1(2) : 1-15

Nugrahani, T.S., Nugroho, F.A. 2010. Pengaruh Komisaris Independen dan Pengungkapan Sukarela terhadap Kinerja Perusahaan.Universitas PGRI Yogyakarta.Karisma 4(2): 132-141

Pathan, Shamsi, Skully, Michael, Wickramanayake, J. 2007. Board Size Idependence and Performance: Analysis of Thai Banks. Asia-Pacific Financial Markets. 14(3): 211-227

Peraturan Bank Indonesia No. 8/4/PBI Tahun 2006

Purba, B. 2014.Analisis Kointegrasi antara Indeks Harga Saham Gabungan Jumlah Uang Beredar dan Indeks Harga Pedagang Besar di Indonesia Periode 2007-2013.Jurnal Santech, 6(4) : 19

Puspitasari, Filia., Ernawati, Endang. 2010. Pengaruh Mekanisme Corporate Governance terhadap Kinerja Keuangan Badan Usaha. Jurnal Manajemen Teori dan Terapan3(2)

Putra A.S., Nuzula N.F. 2017. Pengaruh Corporate Governance terhadap Profitabilitas.Jurnal Administrasi Bisnis (JAB)47(1)

Raja, D.H. Lumban. 2016. Pengaruh Dewan Komisaris, Komisaris Independen, Komite Audit terhadap Profitabilitas pada Perusahaan Sektor Propertydan Real Stateyang terdaftar di BEI. Jurusan Manajemen, Fak.Ekonomi, Universitas Negeri Surabaya 
Rini, T.Sulestyo. 2012. Pengaruh Pemegang Saham Institusi, Komisaris Independen \& Komite Audit terhadap Tingkat Profitablitas Perusahaan. Jurnal Akuntansi 1(1): 1-12

Santoso, Adi. 2016. Peningkatan Profitabilitas pada Industri Perbankan Go-Publik di Indonesia.Jurnal Bisnis dan Manajemen6(1).Ponorogo : Universitas Muhammadiyah

Saputri, S F Henny., Oetomo, Hening Widi. 2016. Pengaruh CAR, BOPO, NPL, FDR terhadap ROE pada Bank Devisa. Jurnal Ilmu dan Riset Manajemen 5(5).Surabaya : Sekolah Tinggi Ilmu Ekonomi Indonesia (STIESIA)

Septiana, Nurul, dkk. 2016. Pengaruh Mekkanisme GCG terhadap Profiitabilitas Perusahaan. Jurnal Administrasi Bisnis (JAB) 38(2)

Setiawaty, Agus. 2016. Pengaruh Mekanisme Good Corporate Governance terhadap Kinerja Perbankan dengan Manajemen Risiko sebagai Variabel Intervening. Jurnal Ekonomi dan Manajemen 13(1). Fakultas Ekonomi dan Bisnis Universitas Mulawarman

Siamat, Dahlan. 2005. Manajemen Lembaga Keuangan. Jakarta : FEUI

Siswanti, Indra. 2016. Implementasi Good Corporate Governance pada Kinerja Bank Syariah. Jurnal Akuntansi Multiparadigma JAMAL7(2): 156-323 Malang, Agustus 2016

Sugiyono. 2012. Statistika untuk Penelitian. Bandung : Alfabeta

Sugiyono. 2013. Metode Penelitian Bisnis. Bandung : Alfabeta

Suhartatik, N., Kusumaningtyas, R (2013). Determinan Financing to Deposit Ratio (FDR) Perbankan Syariah di Indonesia (2008-2012).Jurnal Ilmu Manajemen, 1(4):1179

Surat edaran Bank Indonesia No. 12/13/DPbS tahun 2010

Temewu, Riana Christel., Stanly W. Alexander. 2014. Pengaruh Penerapan Good Corporate Governance terhadap Profitabilitas pada Perusahaan Perbankan yang terdaftar di BEI Periode 2009-2013. Skripsi

Tjandra, Eric. 2015. Pengaruh GCG terhadap Leverage dan Profitabilitas pada Perusahaan property dan Real Estate di Indonesia.Jurnal GEMA AKTUALITA, 4 (2)

Tjondro, David., Wilopo. 2011. Pengaruh Good Corporate Governance (GCG) terhadap Profitabilitas dan Kinerja Saham Perusahaan Perbankan yang Tercatat di Bursa Efek Indonesia. Journal of Business and Banking 1(1): 114. Surabaya : STIE Perbanas Surabaya

Undang-Undang Republik Indonesia No. 10 Tahun 1998

Undang-Undang No.40 Tahun 2007

Wahyudi, Imam, dkk. 2013. Manajemen Risiko Bank Islam. Jakarta : Salemba Empat 
Taufikur Rohman dan Dian Safitri

Wardani, Ratna. 2007. Mekanisme Corporate Governance dalam Perusahaan yang Mengalami Permasalahan Keuangan. Jurnal Akuntansi dan Keuangan 4(1) : 95-114

www.bi.go.id

www.ojk.go.id

Yudiana, Fetria Eka. 2014. Manajemen Pembiayaan Bank Syariah. Salatiga: STAIN Salatiga Press

Yudiana, FetriaEka . 2013. Dasar-Dasar Manajemen Keuangan.Yogyakarta: OMBAK 